\title{
Présentation. Réflexions pour une ethnologie des techniques en Inde
}

\section{Marie-Claude Mahias}

\section{(2) OpenEdition \\ 12 Journals}

Édition électronique

URL : https://journals.openedition.org/tc/759

DOI : $10.4000 /$ tc.759

ISSN : 1952-420X

Éditeur

Éditions de l'EHESS

\section{Édition imprimée}

Date de publication : 1 octobre 1990

ISSN : 0248-6016

\section{Référence électronique}

Marie-Claude Mahias, "Présentation. Réflexions pour une ethnologie des techniques en Inde ", Techniques \& Culture [En ligne], 14 | 1990, mis en ligne le 16 janvier 2006, consulté le 29 septembre 2022. URL : http://journals.openedition.org/tc/759 ; DOI : https://doi.org/10.4000/tc.759

Ce document a été généré automatiquement le 29 septembre 2022.

Tous droits réservés 


\title{
Présentation. Réflexions pour une ethnologie des techniques en Inde
}

\author{
Marie-Claude Mahias
}

